Citation: Aberrahmane, B., Mahri, Z.A., "Analysis of the Effect of Inhabitant Behavior on the Energy Consumption in the Residential Sector in Constantine, Algeria". Journal of Engineering Technology and Applied Sciences 4 (3) 2019 : 125-129.

\title{
ANALYSIS OF THE EFFECT OF INHABITANT BEHAVIOR ON THE ENERGY CONSUMPTION IN THE RESIDENTIAL SECTOR IN CONSTANTINE, ALGERIA
}

\author{
Boursas Aberrahmane ${ }^{a}$, Zine Labidine Mahri ${ }^{\mathbf{a}^{*}}$ \\ ${ }^{a}$ Laboratoire de génie climatique université des frères Mentouri, Constantine, Algeria \\ boursasabdou@hotmail.com, zlmahri@hotmail.com (*corresponding author)
}

\begin{abstract}
This work aims to investigate the energy consumption trend of inhabitants and to study their behavior in order to rationalize this consumption. In this work, a statistical survey was conducted covering 100 homes in the town of Constantine located in the northeast of Algeria, in order to estimate the electricity and gas consumption by the inhabitants and analyzing their behaviors related to this consumption. In the second part of this work, a numerical simulation was carried out using TRNSYS software, for a building for which data were collected by the survey with the aim of determining its theoretical energy consumption and comparing it with real data obtained by the survey.
\end{abstract}

Keywords: Thermal engineering, thermal confort, numerical simulation, TRNSYS software

\section{Introduction}

The sector of building is one of the main targets of the improvement of energy efficiency, since it represents today more than one third of the worldwide consumption of energy and an equivalent amount of its associated emissions [1].

In Algeria, this sector has the highest energy consumption. Its consumption represents more than $42 \%$ of the total final consumption [2].

The objective of this study is to explore the consumption habits of inhabitants and with the aim to rationalize their energy consumption behavior.

In this work a statistical survey was conducted covering 100 homes in the town of Constantine located in north east of Algeria, in order to estimate the electricity and 
gas consumption by the inhabitants and analyzing their behaviors related to this consumption; particularly, by examining their manner of using heating and air conditioning (such as the adjusted temperature and the frequencies of this use). Moreover this survey inspects the type of lighting and the types of the domestic appliances used and the frequencies of this use, as well as the occupancy rate of different rooms of the building by the inhabitants.

In the second part of this work a numerical simulation of several types of building was carried out using TRNSYS software in order to evaluate the thermal performance of these buildings. TRNSYS software allows us to estimate the energy need of heating and air conditioning.

A particular simulation is carried out for a special type of building for which the data were collected by the survey with the aim of determining its theoretical energy consumption and comparing it with real data obtained by the survey.

This comparison allows us to study the potential of energy saving by improving the building characteristics [3] (particularly by improving its envelope) on one hand and on the other hand by raising awareness of the inhabitants in order to adjust their practices toward a more rational behavior as regards energy consumption [4].

\section{Study of energy consumption in the residential sector using a survey}

In this part of the work a statistical survey was conducted covering 100 residences in Constantine, in order to estimate the electricity and gas consumption and analyze the consumption trend and the behavior of the users with the aim of rationalizing this consumption.

This survey consists of collecting data for each household such as: the type of construction and its envelope, the number of inhabitants per residence, the position of this house with respect to neighboring houses, the type of lighting and equipments used in each house and their power and the habits of use of these facilities. Also energy bills for gas and electricity were collected and analyzed.

The questionnaire used in this study contains the following elements:

a- Information about the household and the type of construction.

b- Appliances used daily.

c- Heating and air conditioning equipment.

Some results of this survey can be summarized as follow:

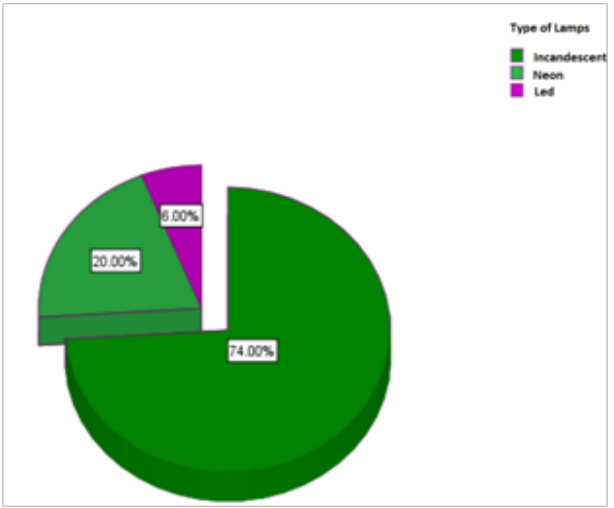

Figure 1. Percentage of the type of lighting used 


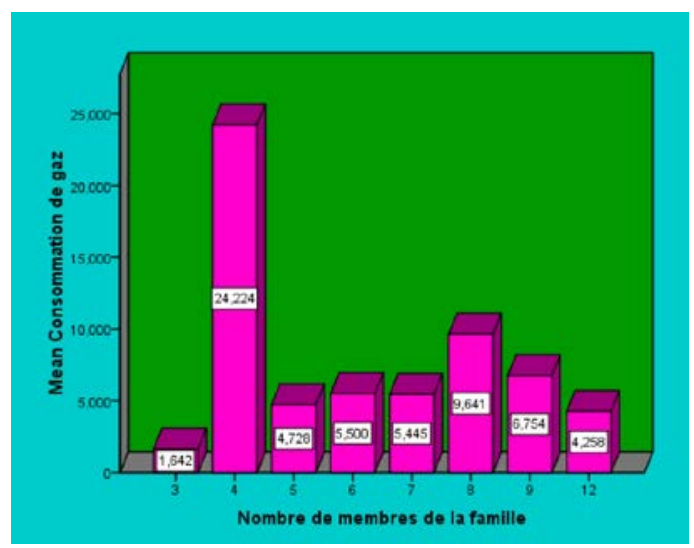

Figure 2.Vaiation of gas consumption (kWh) with respect to the number of family members

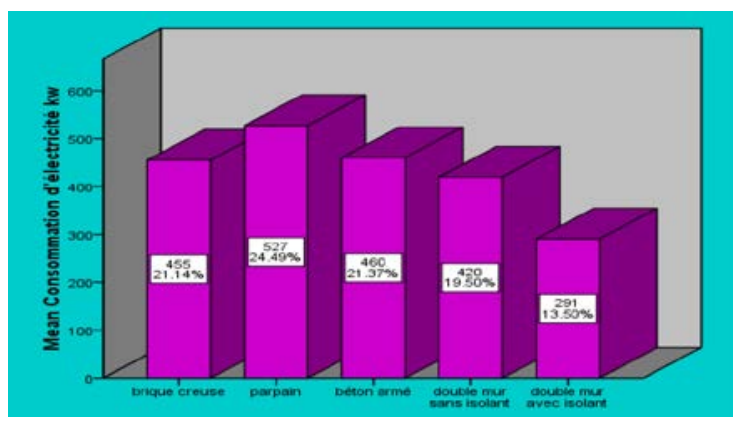

Figure 3.Vaiation of electricity consumption (kWh) with respect to the wall type

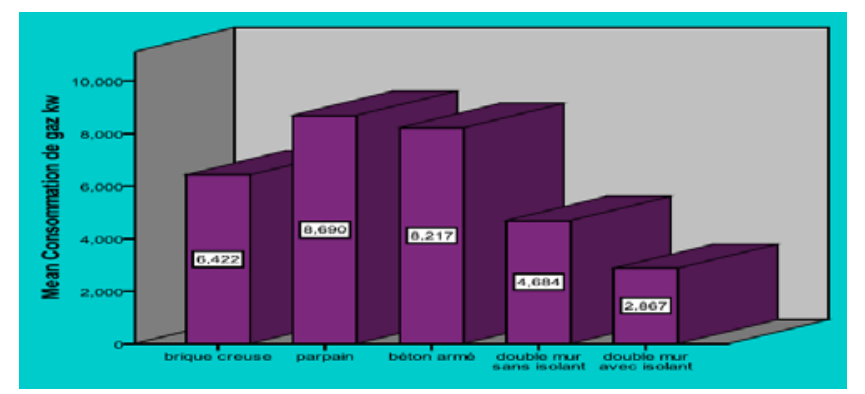

Figure 4.Vaiation of gas consumption (kWh) with respect to the wall type

\section{Thermal simulation using TRNSYS software}

In the second part of this work a numerical simulation was carried out using TRNSYS software for a particular building for which the data were collected by the survey with the aim of determining its theoretical energy consumption and comparing it with real data obtained by the survey.

This comparison allows us to study the potential of energy saving by improving the building characteristics (particularly by improving its envelope) on one hand [5] and on the other hand by raising awareness of the inhabitants in order to adjust their practices toward a more rational behavior as regards energy consumption [6].

The results of this simulation can be summarized as follow: 


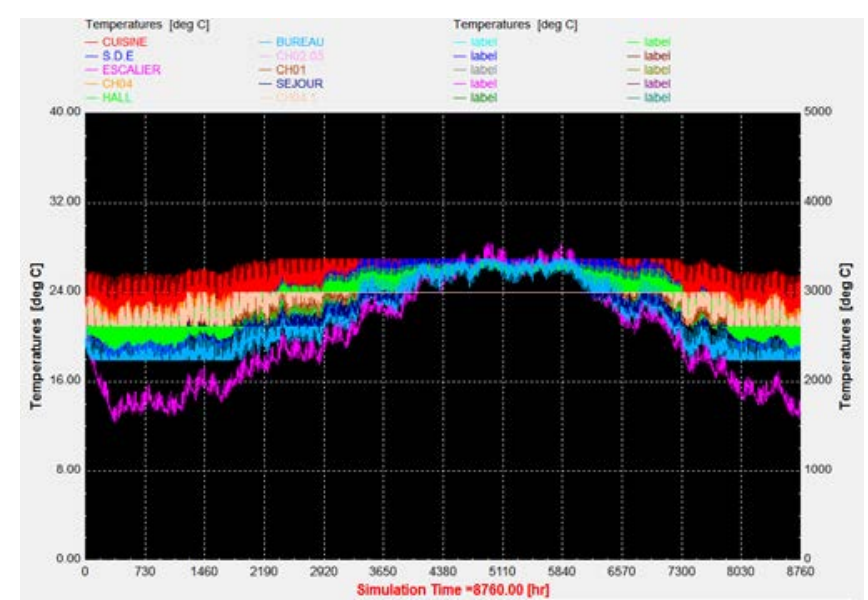

Figure 5.Temperature distribution throughout a year for each room

Table 1. Monthly and annual Energy need (consumption) for heating a cooling throughout a year

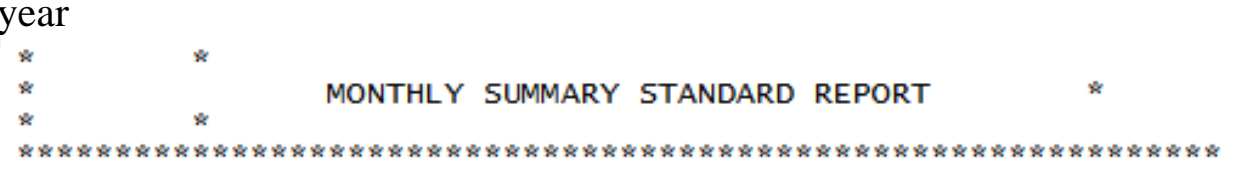

\begin{tabular}{|c|c|c|c|c|}
\hline MONTH & $\begin{array}{l}\text { HEATING } \\
\text { [KWH] }\end{array}$ & $\begin{array}{c}\text { COOLING } \\
\text { [KWH] }\end{array}$ & $\begin{array}{l}\text { INFILTR. } \\
{[\mathrm{KWH}]}\end{array}$ & $\begin{array}{l}\text { VENTILAT. } \\
\text { [KWH] }\end{array}$ \\
\hline JAN & $1.815 \mathrm{E}+03$ & 8. $777 \mathrm{E}+01$ & $-2.673 \mathrm{E}+03$ & $0.000 \mathrm{E}+00$ \\
\hline FEB & 1. $382 \mathrm{E}+03$ & 9. $633 \mathrm{E}+01$ & $-2.296 \mathrm{E}+03$ & $0.000 \mathrm{E}+00$ \\
\hline MAR & $7.608 \mathrm{E}+02$ & 1. $912 \mathrm{E}+02$ & $-2.355 E+03$ & $0.000 \mathrm{E}+00$ \\
\hline APR & 1. $827 \mathrm{E}+02$ & $4.144 E+02$ & $-2.074 E+03$ & $0.000 \mathrm{E}+00$ \\
\hline MAY & 1. $274 \mathrm{E}+01$ & 1. $299 \mathrm{E}+03$ & $-1.704 E+03$ & $0.000 \mathrm{E}+00$ \\
\hline JUN & $0.000 E+00$ & $2.484 E+03$ & $-1.188 E+03$ & $0.000 \mathrm{E}+00$ \\
\hline JUL & $0.000 \mathrm{E}+00$ & $4.005 \mathrm{E}+03$ & $-5.749 \mathrm{E}+02$ & $0.000 \mathrm{E}+00$ \\
\hline AUG & $7.499 \mathrm{E}-07$ & 3. $923 \mathrm{E}+03$ & $-5.672 \mathrm{E}+02$ & $0.000 \mathrm{E}+00$ \\
\hline SEP & $0.000 E+00$ & $2.463 \mathrm{E}+03$ & $-1.054 E+03$ & $0.000 \mathrm{E}+00$ \\
\hline OCT & 1. $384 \mathrm{E}+01$ & 1. $049 \mathrm{E}+03$ & $-1.530 E+03$ & $0.000 E+00$ \\
\hline NOV & $5.737 E+02$ & 1. $989 \mathrm{E}+02$ & $-2.047 E+03$ & $0.000 \mathrm{E}+00$ \\
\hline DEC & $1.608 \mathrm{E}+03$ & 9. $399 \mathrm{E}+01$ & $-2.456 \mathrm{E}+03$ & $0.000 \mathrm{E}+00$ \\
\hline SUM & 6. $348 \mathrm{E}+03$ & $1.631 \mathrm{E}+04$ & $-2.052 \mathrm{E}+04$ & $0.000 \mathrm{E}+00$ \\
\hline
\end{tabular}

SOLAR_RAD. INT_GAINS $[\mathrm{KWH}] \quad[\mathrm{KWH}]$

$6.412 \mathrm{E}+02 \quad 3.286 \mathrm{E}+03$

$6.935 \mathrm{E}+02 \quad 2.869 \mathrm{E}+03$

9. $707 \mathrm{E}+02 \quad 3.125 \mathrm{E}+03$

1. $060 \mathrm{E}+03 \quad 2.953 \mathrm{E}+03$

1. $257 \mathrm{E}+03 \quad 3.079 \mathrm{E}+03$

1. $266 \mathrm{E}+03 \quad 2.930 \mathrm{E}+03$

1. $367 \mathrm{E}+03 \quad 3.023 \mathrm{E}+03$

1. $326 \mathrm{E}+03 \quad 3.081 \mathrm{E}+03$

$1.111 \mathrm{E}+03 \quad 2.927 \mathrm{E}+03$

8. $769 \mathrm{E}+02 \quad 3.163 \mathrm{E}+03$

6. $291 \mathrm{E}+02 \quad 3.145 \mathrm{E}+03$

$5.735 \mathrm{E}+02-3.213 \mathrm{E}+03$

1.177E+04 3.679E+04

\section{Conclusion}

The statistical survey conducted covering 100 residence in the city of Constantine has enabled us to draw the following conclusions:

- Approximately 33\% of constructions are made of materials with poor thermal characteristics such as concrete blocks.

One can notice the low use of thermal insulation in these buildings, with a maximum of $5 \%$ of buildings thermally insulated.

The numerical simulation has shown that the improvement of the envelope allows an energy saving of more than $40 \%$.

- About $3 / 4$ households use high energy-consuming lamps (incandescent lamps) while the use of low-consumption LED lamps is very low.

- The collective residence consume almost half that individual houses.

- The gas consumption is more important for the isolated areas than for the zones located in 
an urban area.

- A small number of inhabitants does not necessarily imply a reduction in energy consumption, this is due to the irrational attitude of the inhabitants.

- The actual consumption resulting from the questionnaire is higher than that obtained by the simulation by $17 \%$, this is due also to the irrational behavior of the users."”

\section{References}

[1] Agence Nationale pour la Promotion et la Rationalisation de l'Utilisation de l'Energie (APRUE, Algeria)., Programme de développement de l'efficacité énergétique à l’horizon 2030 (2015) :4-9.

[2] SATINFO Société du Groupe Sonelgaz., "Programme des énergies renouvelables et de l'efficacité énergétique”,Ministère de l'énergie et des mines (2011) : 4-6.

[3] Ould-Hennia, A., "Choix climatiques et construction, zones arides et semi-arides : la maison à cour de Boussaâda”, Thèse de doctorat, école polytechnique Fédérale de Lausanne, Suisse (2003).

[4] Givoni, B., “L’homme, l’architecture et le clima”, Editions du Moniteur, Paris (1978).

[5] Sam, F., "Réhabilitation thermique d'un local dans une zone aride", mémoire de Magister faculté du génie de la construction, département de génie mécanique, Université Mouloud Mammeri De Tizi Ouzou (2012).

[6] Thiers, S., "bilans énergétiques et environnementaux de bâtiments à énergie positive”, Thèse de Doctorat, Ecole Nationale Supérieure Des Mines De Paris (2008). 